Experimental Techniques for the Detection of Ion Movement in Solids, Socicty for Electrochemistry, Solid State Sub-Group, at
the Atomic Energy Research Fstablishment, Harwell, Didcot, Berks.

Low-light Vision (2.30 p.m. colloquium) Institution of Llectrical Enginecrs, at Savoy Place, London WC2.

Models and Molecules $(9$ p.m. $)$ Professor W. D. Ollis, Royal Institution, at 21 Albemarle Street, London W1.

Non-standard Analysis. I. Analytic Theory of Polynomicals $(5.30$ p.m.) Professor $\Lambda$ braham Robinson (Yale University), University WC1.

Spring Scientiflc Mceting (11.30 a.m.) Fisherics Society of the I3ritish Isles, in the Large Meetirig Room of the Zoological Society, Regent's
Park, London NW1.

Monday, April 27

Apprenticeship and Industrial Training (6 p.m.) Mr Cyril $\mathrm{K}$. English, Royal Society of Arts, at John Adam Strect, London WC2. (Sccond of three Cantor Lectures on Training for Industry.)

Contact Problems in Machines using Thyristor Assisted Communication $(5.30$ p.m.) Professor J. J. Bates, Mr S. Stanway and Mr R. F. Sansum, lnst

Escalators and Travolators (6 p.m.) Mr C. W. Hardic, Institution of Mechanical Engineers, at 1 Birdcage Walk, London SW1.

Gunn Domain Logic (5.30 p.m.) Dr H. L. Hartnagel, Institution of Electrical Engineers, at Savoy Place, London WC2.

Quasi-stellar Objects $(5.30$ p.m.) Professor G. Burbidge (Cniversity of California), University College London, in the Physics Theatre,

The Evolution of a Microbial Metabolic Pathway (5.30 p.m.) Professor Roger Y. Stanier (University of California), University College Loridon, in the Botany Theatre, Gower Street, London WC1.

\section{Reports and Publications}

(not included in the monthly Books Supplement)

\section{Great Britain and Ireland}

Water Resourecs Board. TN 9 (revised): Metrication. (i1. T.X. 11 The Gvaluation of Errors at Flow Measurement Stations. By R. W. Herschy.
Py. 31. (Reading: Water Resources Board, 1969.) Py. 31. (Reading: Water Resources Board, 1969.)
BBC Engineering Monograph No. 80: An Automatic Method for tho Measurement of Reverberation Time. By Dr M. E. B. Mollat, and N. F' Spring. Pp. 18. (Iondon: BBC, 1969.) 5s. Accelerating Innovation. (Papers given at a Symposium held at th with the Ministry of Technology and the Research Associations.) P P. 64 . (London: Aslib, 1970.) 35s net (30s net to Aslib members).

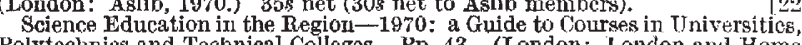
Polytechnies and Technical colleges. Pp. 43. (London: London and Home Counties Regional Advisory Council for Techuological Education, 1970 .) Bulletin of the British Museum (Natural History). Entomology. Vol. 24 , No. 5: A Revision of the Cenus Catoptropteryx Karsch (Orthoptera: 'l'ettigoniidac) By J. Huxley. Pp. 127-170+1 plate. (London: British Museum British Steel Corporation. BISRA Annual leport for the year ending September 30th, 1969. Pp. 87. (London: The British Iron and Stcel Research Association, 1970.) List of Research Grants Current on Octolyer 1 Science Research Council. List of Research Grants Current on Octolver 1,
1969. Pp. 123, (London: Science Research Council, 1970.) 1969. Pp. 123, (London: Science Research Council, 1970.)
Youth Exchanges: The Way Ahead. By Alan Evans. Propared by Political and Economic Planning for the Furopean Educational Research Trust. Pp. 63. (A Europe House Publication.) (London: Political and Marconi-Hilliott Microelectronics. MST and Memory Elements Product Guide. Pp. 16. (Witham, Essex: Marconi-Elliott Microelectronics Itd., Guide. Pp. 16. (Witham, Essex: Marconi-Elliott Microelectronics Itd., Genesis Two ("Naught but Zeus")-The Semele Theory of Planetary
origin. By Douglas Rookes. Pp. 40. (London: Ardilla Books, 1970.) 10 imperial College of Science and Technology (Lniversity of London). Sixty-second Annual Report of the Governing Body, 1968/1969. Pp.
vit 186. (London: Imperial College of Science and Tcchnology, 1970.) [92

\section{HOW TO BUY NATURE}

Volumes start in January, April, July and October but subscriptions may begin with any issue.

The direct postal price per subscription for one copy of NATURE each week is :

*12 MONTHS (52 issues and 4 indexes)

Great Britain and Eire.................... 14.0 .0 each

United States of America........ (by air freight) .........\$48 each

Canada ................... (by air freight) ....... \$52 each

Elsewhere overseas by surface mail

. 14.0 .0 each

(Charge for delivery by air mail on application)

* Shorter periods pro rata. (Minimum three months.)
University of Leeds and the United Leeds Hospitals. An Experiment in Iospital Catering Using the Cook/Freeze System. Pp. 40. (Lceds: Procter Department of Food and Leather Science, The University, 1970.) [92 Building Rescarch Station. Curreni Paper 51/69: Accuracy of Measure1969, Sept. 19.) (Garston, Batford: Building Research Station, 1969.) Gratis. 282: Toughened Glass Windscreen Injuries in Car Occupants. By ... Grattan, N. (. . Clegg and J. A. Hobbs. Pp. $6+6$ plates. (Crowthorne,
Berkshire: Road Rebearch Laboratory, 1969.) Gratis.

\section{Other Countries}

Science Council of Canada. Special Study No. 8: Scientific and Technical Information in Carada, Part 2. Chapter 2: Industry. Pp, $\mathrm{x}+80$. (Ottawa Queen's L'rinter, 1969.) \$1.25. India: Council of Scientific and Industrial Research. Annual Report of the Central Mining Research Station, 1968/1969. Pp. 250. (Thanbad, Arthur D. Little, lnc., Trecisions. Pp. 24. Directions. Pp. 24. (Cambridge, Mass.: Arthur 1 . Little, Inc., 1969.) Directions. Pp. 24. (CamIndia. Fornst Research Institute, Johra Dun. Indian Forest Jealfet Strength of Nail-Joined Timber Roof Trusses for Residential Buildings. Part 1.: 3 to 6 Metres, Destructive Testa. By N. J. Masani and R. K. Gupta. P'p. 14. (I) 6 hi : Manager of Publications, 1969.) Rs. $3.40 ; 8 s ; \$ 1.23$. [151 Antarctic Ice Shelf. By Torgny t. Vinje. Pp. 55. (Oslo: Norsk Polarinstitutt, 1969.)
Trace Mineral Studies with Isotopes in Domestic Animals Trace Mineral Studies with Isotopes in Domestic Animals. (Proceedings of a Punel on the Use of Isotopes in Studies of Mincral Metabolism and Disease in Domestic Animals organized by the Joint FAO/LAEA Division of Atomic Tnergy in Food and Agriculture, held in Vienna, 28-31 October
1968. (Panel Proceedings Series.) Pp. 151. (Vicnua: International Atomic Huergy Ageney; London: IIM Stationery Office, 1969.) 104 schillings; 33s 4d; $\$ 4$.
Advisory Council on (College Chemistry, Stanford University. Catalogue Advisory Council on (Gollege Chemistry, Stanford University. Catalogue
of Instruetional Films (16 mun, Super 8 , and $8 \mathrm{~mm}$ ) for College Chemistry. of Instruetional Films (16 mun, Super 8, and $8 \mathrm{~mm}$ ) for College Chemistry.
(Serial Publication No. 42.) Pp. 196. (Stanford, Calif.: Advisory Council (Serial Publication No. 42.) Pp. 196. (Stanford, Calif.: Advisory Council
on Collcge Chemistry. The University, 1969.) International Association of Universities. 1969 World List--Universities; other Institutions of Higher Education; University Organizations. Pp. xviii + 406. (Paris: International Association of Universities, 1969.) 「191
Is Dcpartment of the Interior: Geological Survey. Water-supply Paper 1850-B: Floods of June 1965 in South Platte River Basin, Colorado. Pp. iv + 64 + plates 1-4. (Washington, DC: Government Printing Office, Pp. iv + 64 + plates 1-4. (Washington, DC: Government Printing Office,
[1969.) \$1. Berichte des Deutschen Wetterdienstes. Nr. 114 (Jand 24): Beitrag Von Paul 1. Bock. Pp. 37. Nr. 115 (Band 15): Langjahrige Monats- und Jahresmittel der Lufttempratur und des Niederschlags in der Bundesrcpnblik Deutschland für die Periode 1931-1960. Von Hans Sohirmer. (Offenbach a.M.: Sclbstverlag des Deutschen Wetterdienstes, 1969.) [191 World Health Organization. Technical Report Series, No. 435: Biologifal tion Groups-Report of a WHO Scientific Groun of their Variations in PopulaHealth Organization; London: HM Stationery Office, 1969.) 3 Sw. Wrancs. 6s; \$1.
Harvard University Program on Technology and Society. Fifth Annual Report 1968/1969. Pp, 82. (Cambridge, Mass.: Harvard University, 1969.) Coopcration Iuternatiouale. Culturelle, Scientifioue ot Technigne1 La Coopcration Internationale: Culturelle, Scientificue th TechniqueAbonnement pour les Numéros 1 et 2 (Annee 1970). (Nice: Faculté de Troit et des Seiences Economiques de l'Tiniversité de Nice, 1969.) 50 [ranes.
TJnesco. Annual Summary of Information on Natural Disasters, No. 1 1966. Pp. 81. (Paris: Unesco, 1970.) 14 francs; $218 ; \$ 3.50$.
[201 Science, Technology, and Public Policy: a Selected and Annotated Bibliography. Edited by Lynton $\mathrm{k}$. Caldwell. Assisted by William B. DeVille and Gertrude W. Lindesmith. Vol. 2: Articles in Jourmals. Pp.
xil +544. (Bloomington, Indiana: The Program of Advanced Studies in Science, lechnology, and Society, Department of Government, Indiana Science, 'lechnology, and Society, Department of Government, Indiana
University, 1969. Prepared for the National Science Foundation.)
[201 US Department of Commerce-Environmental Scicnce Services Adminis1968. 39 reprints. (Washington, DC: Government Printing Office, 1969.) \$3.25.
\$211 Publications do I'1nstitut Suisse de Météorologie. Nr. 13: Contribution a la Méthodolngie Granulométrique des Aćrosols Amicoscopiques. Par A Junod. Pp. 70. Nr. 14: Untersuchungen zur Quantitatlven Bestimmung von Niederschlagsmengen Mittels Radar, Von J. Joss, Karin Schrim, J. C. Svizzera, 1969) Waldvogel. Pp. 37. (Locano-Monti: Ccntrale Meteorologrica
Editorial and Publishing Offices of "NATURE" MACMILLAN (JOURNALS) LIMITED

4 LITTLE ESSEX STREET, LONDON WC2

Telephone Number: 01-836 6633. Telegrams: Phusis London WC2 Subscription Department MACMILLAN (JOURNALS) LIMITED

BRUNEL ROAD, BASINGSTOKE, HANTS Telephona Number: Basíngstoke 5431

Advertisements only should be addressed to T. G. SCOTT \& SON, LIMITED

I CLEMENT'S INN, LONDON WC2A 2ED Telephone 0I-242 6264;01-405 4743 Telegrams: Textualist London WC2

Registered as a newspaper at the Post Office

Copyright (C) Macmillan (Journals) Limited, April 18, 1970 